\title{
Multidimensional Analysis of Fish Diversity on Lake Issyk-Kul
}

\author{
Aliiaskarov Mail Aliiaskarovich ${ }^{1 *}$, Sarieva Mairam² ${ }^{2}$, Djenbaev Bekmamat Myrzakmatovich ${ }^{3}$ and Asylbaeva \\ Shaigul Makeshovna ${ }^{4}$
}

${ }^{1}$ Deputy Director of the fisheries Department of the Ministry of agriculture, food industry and melioration of the Kyrgyz Republic

${ }^{2}$ Coordinator of the FAO project Sustainable development of aquaculture and fisheries in the Kyrgyz Republic

${ }^{3}$ Doctor of biological Sciences, chief scientific Secretary of the national Academy of Sciences of the Kyrgyz Republic

${ }^{4}$ Head of the laboratory of Ichthyology and Hydrobiology of the National Academy of Sciences of the Kyrgyz Republic

Submission: September 14, 2020; Published: November 13, 2020

Corresponding author: Aliiaskarov Mail Aliiaskarovich, Deputy Director of the fisheries Department of the Ministry of agriculture, food industry and melioration of the Kyrgyz Republic, 96 " a "Kievskaya str., Bishkek, Kyrgyz Republic, Russia

Abstract

Studying the biodiversity of Issyk-Kul lake is one of the most important issues for assessing the state of its ecosystem, as well as determining the strategy for managing and preserving the bioresources of the lake. To study the biodiversity of the aquatic ecosystem, there are various approaches and methods for determining it. This article presents a research paper that was conducted to determine the biodiversity of fish species on lake Issyk-Kul and methods for calculating them through the Shannon-Weiner biodiversity index, the Simpson index (D) and the Simpson diversity index (1 - D). Biodiversity indices are a measure of species richness (the number of species in situ) and their uniformity of distribution in a body of water. The analysis of data on catches was carried out using a multidimensional analysis of the main components of PCA (principle component analysis). The statistical software package MINITAB (version 16) was used to perform PCA analysis. In this regard, the results of the above methods determined the species and dominant composition of fish species, their uniformity and distribution in the studied areas of lake Issyk-Kul.

Keywords: Lake Issyk-Kul; Lake ecosystem; Biodiversity; Shannon-Weiner biodiversity index; Simpson index; Main component Analysis

\section{Relevance}

For hundreds of years, lake Issyk-Kul has been important as the main fishing reservoir of the Kyrgyz Republic - a source of fish resources extraction, as well as a recreation facility for the creation of health resorts [1,2]. Irrational fishing, widespread illegal, unregulated year-round fishing, the presence of introduced predatory fish species, the reduction of programs for annual harvesting of valuable fish species, overregulation of rivers suitable for spawning fish and other reasons led to a catastrophic decline in the fish productivity of the lake Issyk-Kul. Modern anthropogenic influences, including solid household waste and wastewater, also have a negative impact on the ecology of the lake as a whole [3]. To restore and preserve the biological diversity and condition of lake Issyk-Kul, the government of the Kyrgyz Republic has adopted a few legislative, regulatory, and legal acts and state programs for its restoration. However, despite all the efforts made, every year there is a decline in the biodiversity and viability of the lake ecosystem, and the number of endemic fish species of lake Issyk-Kul is on the verge of extinction.

During the period of planned economy, since 1965, due to mass fishing, the total stocks of fish species decreased every year, and at the same time the number of especially valuable endemic fish species decreased Issyk-Kul. Prior to the moratorium (1998), lake Issyk-Kul was divided into 40 fishing areas. Each site, except for protected areas, was assigned to separate fishing teams, where each team tried to exceed the approved catch plans (limits) and competitive actions were conducted between teams of fishermen. Thus, industrial trapping led to an additional load on the lake's aquatic biological resources, which resulted in a reduction in fish stocks and anthropogenic pressure on the lake's ecosystem [4]. Currently, effective measures for the management and conservation of existing fish stocks, as well as daily monitoring of the biological diversity of their quality and quantity of distribution are necessary for" careful " fishing. 


\section{Materials and Methods}

11 sites on lake Issyk-Kul were selected as objects of research. Statistical data on commercial fish production, indicators on reproduction and stocking of the lake with young fish from 1964 to 2019 and their results of the study conducted to determine the biodiversity in 2017-2018 are analyzed. For catching fish specimens and collecting ichthyological material, we used shutter nets with the size of yaks from $10 \times 10 \mathrm{~mm}$ to $70 \times 70 \mathrm{~mm}$. two to four meters high and 100 meters long. Figure 1 shows a schematic map of the selected areas of the lake where control fish catches were conducted. During the research, a representative ichthyological material was collected for analysis, with a total of 860 fish specimens. Captured fish specimens were studied and examined according to the generally accepted method of Pravdina, 1966. Each individual fish specimen was recorded, the place and time of catch, the size was determined by the generally accepted smitt method (Figure 2), the weight measure is reflected in grams. For the main length of the fish body, the distance from the leading edge of the snout tip to the outer end of the middle rays of the caudal fin was measured (AC - the size of the fish length according to Smitt, gh - the greatest height of the fish body) [1].

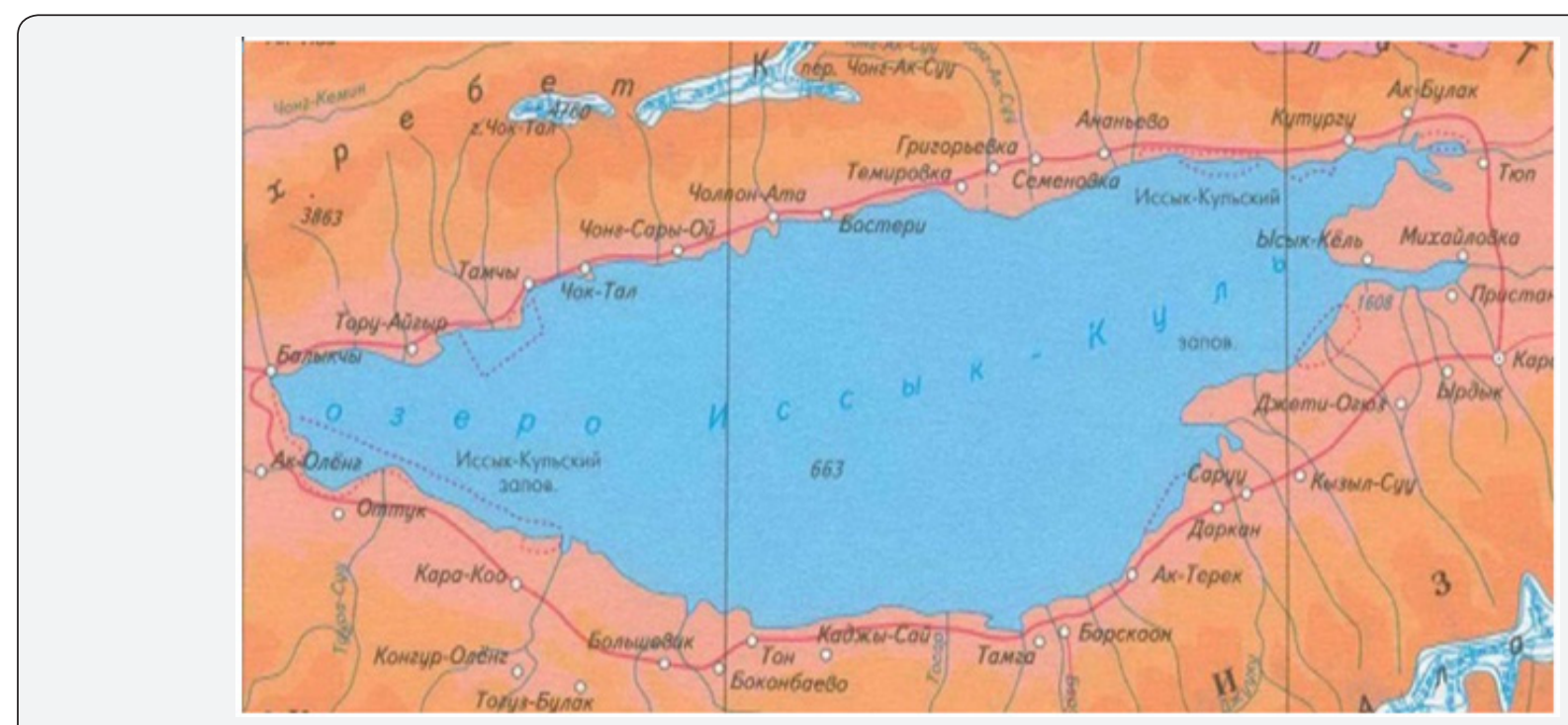

Water sampling sites: Kuturgu, Mikhaylovka, Boz-Beshik, zhenish, Tamga, Kazhi-say, Ottuk, Balykchy, Chok-Tal, Bosteri, Semyonovka Figure 1: Map-scheme of sections of the lake Issyk-Kul

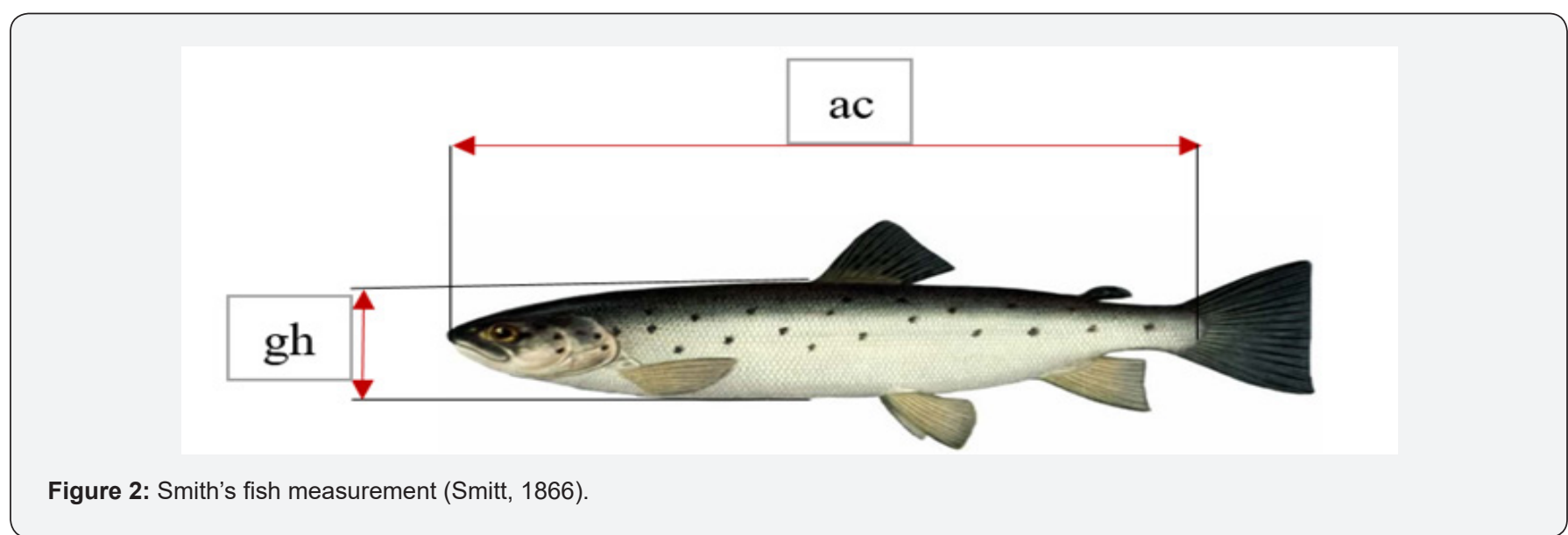

The species composition of the lake is determined based on PCA (principle component analysis). Basic component analysis (PCA) is a classification method for analyzing large amounts of data. The statistical software package MINITAB (version 16) was used to perform the PCA. The Shannon biodiversity index $\left(\mathrm{H}^{\prime}\right)$ at each site was determined using the following equation (Shannon and weaver 1949) [5].

$$
H^{\prime}=-\sum_{i=1}^{s} P_{i}\left(\ln P_{i}\right)
$$

$\mathrm{H}^{\prime}$ ' the amount of diversity in the site / population/ ecosystem. The higher the $\mathrm{h}$ 'score, the more species with relatively similar abundance

$\mathrm{Pi}$ - relative abundance of each individual species 
$\mathrm{i}=(\mathrm{i}=1)$ - value of relative taxonomic abundance

$\mathrm{S}$ - total number of taxa in the studied fish habitat

The results of the Shenon index were associated with the PC1 assessment of the species composition in 11 studied sections of the lake.

\section{Results of Research and Discussion}

Species composition of fish catches was from 11 lake sites, plots were established based on species composition using PCA are shown in Table 1. It should be noted that the species composition indicated in Table 1 , converted in the fourth square root [6]. In the PCA Analysis, the first 4 main components explained $79.4 \%$ of the total variance (Table 2). The first two components explained the cumulative dispersion of $51.4 \%$ and therefore the two-dimensional setup is sufficient to illustrate the setup of 11 sampling sites based on the composition of fish species (Figure 3). On the positively loaded sections of the first axis of the first component, chebak dominated, while in the negatively loaded part of the first axis of the PC, walleye, bream, and carp dominated. Accordingly, such areas as Tamga, AK Bulun (near Boz Beshik), Kaji-say and boster were areas where chebak dominated and the tyupsky area (near Mikhaylovka) were dominated by walleye, bream, and carp.

Table 1: Species composition of fish selected from 11 sites of Issyk-Kul lake.

\begin{tabular}{|c|c|c|c|c|c|c|c|c|c|}
\hline Region & White fish Plot & Perch & Chebak & Trout & Marinka & Bream & Chebachok & Carp & Gubach \\
\hline Kuturgu & 0.117 & 0.050 & 0.000 & 0.000 & 0.000 & 0.107 & 0.000 & 0.000 & 0.000 \\
\hline Mikhailovka & 0.000 & 0.572 & 0.000 & 0.094 & 0.000 & 0.571 & 0.000 & 1.000 & 0.000 \\
\hline Boz-Beshik & 0.245 & 0.000 & 0.185 & 0.256 & 0.000 & 0.000 & 0.000 & 0.000 & 0.000 \\
\hline Zhenish & 0.069 & 0.082 & 0.000 & 0.026 & 0.000 & 0.000 & 0.000 & 0.000 & 0.000 \\
\hline Tamga & 0.000 & 0.000 & 0.111 & 0.000 & 0.000 & 0.000 & 0.706 & 0.000 & 0.000 \\
\hline Kajy-Sai & 0.038 & 0.000 & 0.000 & 0.068 & 0.000 & 0.000 & 0.000 & 0.000 & 1.000 \\
\hline Ottuck & 0.000 & 0.000 & 0.000 & 0.171 & 0.000 & 0.000 & 0.000 & 0.000 & 0.000 \\
\hline Balykchy & 0.176 & 0.132 & 0.000 & 0.000 & 1.000 & 0.000 & 0.000 & 0.000 & 0.000 \\
\hline Chok-Tal & 0.128 & 0.069 & 0.136 & 0.308 & 0.000 & 0.107 & 0.118 & 0.000 & 0.000 \\
\hline Bosteri & 0.000 & 0.000 & 0.444 & 0.077 & 0.000 & 0.000 & 0.000 & 0.000 & 0.000 \\
\hline Semenovka & 0.131 & 0.019 & 0.000 & 0.000 & 0.000 & 0.000 & 0.176 & 0.000 & 0.000 \\
\hline
\end{tabular}

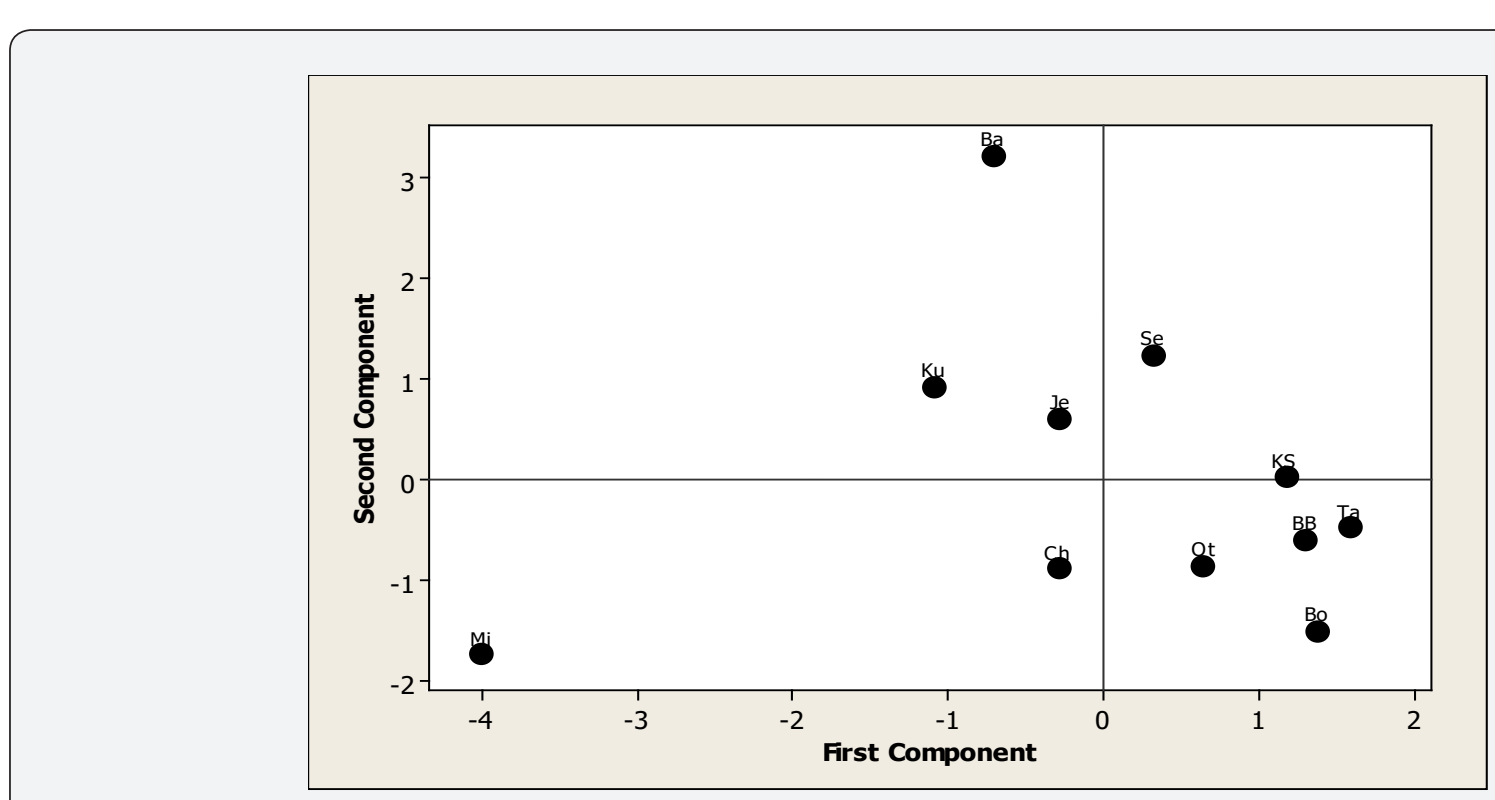

Ku: Touturgu, Mi: Mikhaylovka, BB: Boz-Besik, Je: Zhenish, Ta: Tamga, KS: Everyday-Say, Ot: Ottuk, Ba: Balykchy, Ch: Chok-Tal, Bo: Bosteri, Se: Semyonovka

Figure 3: Two-Dimensional CAP coordination of 11 sampling sites based on the species composition of lake Issyk-Kul. (Cap - related analysis of Principal coordinates, With on strained Analysis of Principal Coordinates). 


\section{Oceanography \& Fisheries Open access Journal}

Table 2: Results of PCA of species composition in 11 fish sampling sites on lake Issyk-Kul. Highlighted in bold.

\begin{tabular}{|c|c|c|c|c|}
\hline & PC1 & PC2 & PC3 & PC4 \\
\hline Eigenvalue & 2.581 & 2.042 & 1.522 & 0.999 \\
\hline The difference in percentage & 0.287 & 0.227 & 0.169 & 0.111 \\
\hline The total variance of Variables & 0.287 & 0.514 & 0.683 & 0.794 \\
\hline Whitefish Variables & 0.026 & 0.446 & -0.097 & 0.504 \\
\hline Zander & -0.564 & 0.187 & 0.122 & 0.133 \\
\hline Chebak & 0.308 & -0.348 & 0.325 & 0.442 \\
\hline Trout & 0.014 & -0.492 & -0.346 & 0.468 \\
\hline Marinka & -0.092 & 0.523 & -0.011 & 0.190 \\
\hline Bream & -0.512 & -0.224 & 0.107 & 0.091 \\
\hline Chebachok & 0.167 & -0.020 & 0.623 & -0.302 \\
\hline Carp & -0.514 & -0.281 & -0.028 & -0.178 \\
\hline Gubach & 0.150 & 0.004 & -0.591 & -0.384 \\
\hline
\end{tabular}

The relationship between the Shannon diversity index and estimates of the first major component of PCA coordination based on species composition is shown in Figure 4. The given graphic analysis shows that the tup site (near Mikhaylovka) is the place with the highest species diversity of fish and a distributed site. Places like Bosteri and Tamga have the lowest fish species diversity. The analysis of annual fish production data, which reflects the graph below (Figure 5), indicates a sharp decline in fish production on lake Issyk-Kul. The dominance of predatory fish species in catches may be one of the reasons for the decline in fishing production in the lake (Figure 6).

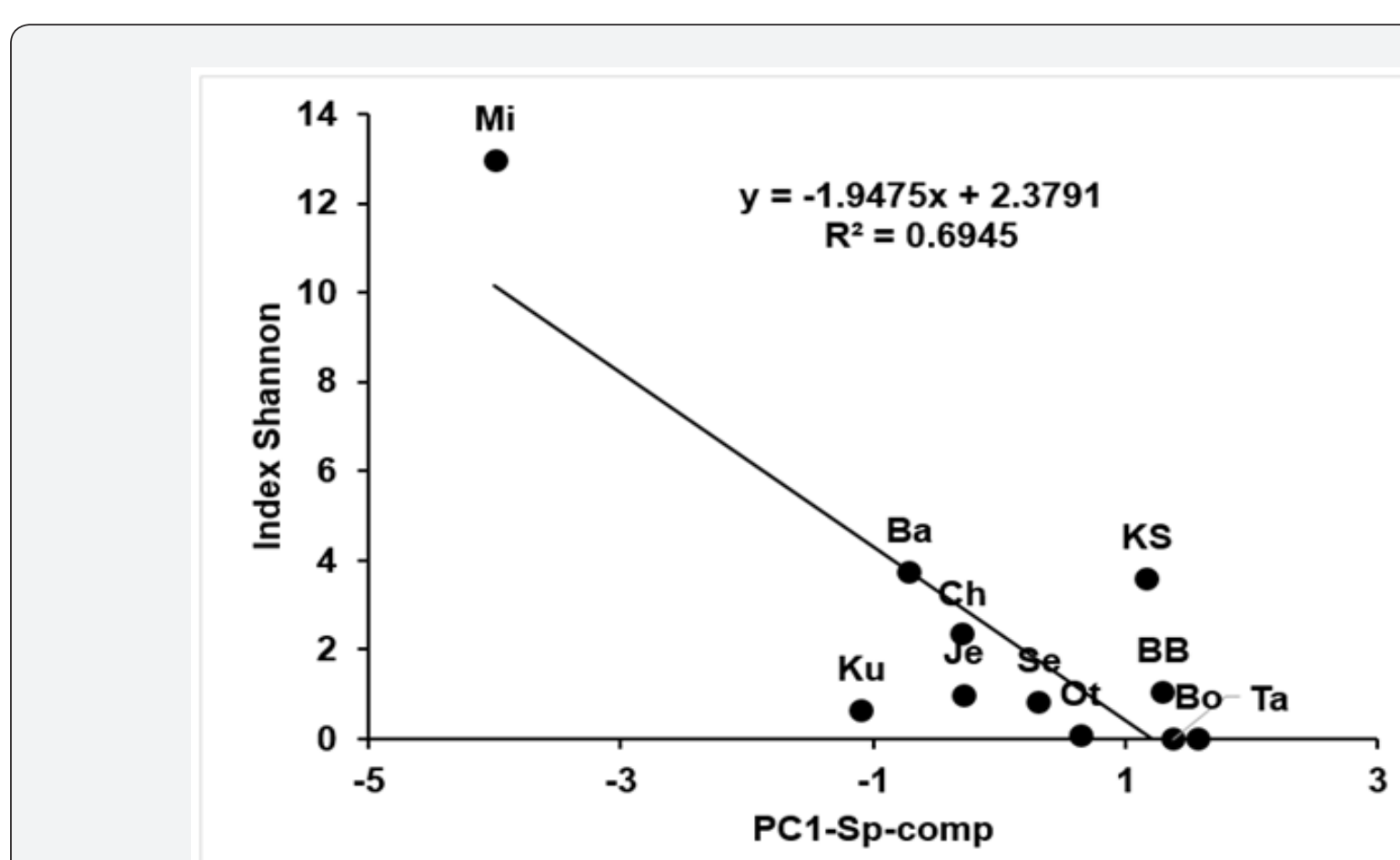

Ku: Touturgu, Mi: Mikhailovka, BB: Boz-Beshik, Je: zhenish, Ta: Tamga, KS: Kazhisay, Ot: Ottuk, Ba: Balykchy, Ch: Chok-Tal, Bo: boster, Se: Semenovka.

Figure 4: Relationship between the Shannon diversity index and PC1 estimates based on species composition in 11 sampling sites in lake Issyk-Kul. 


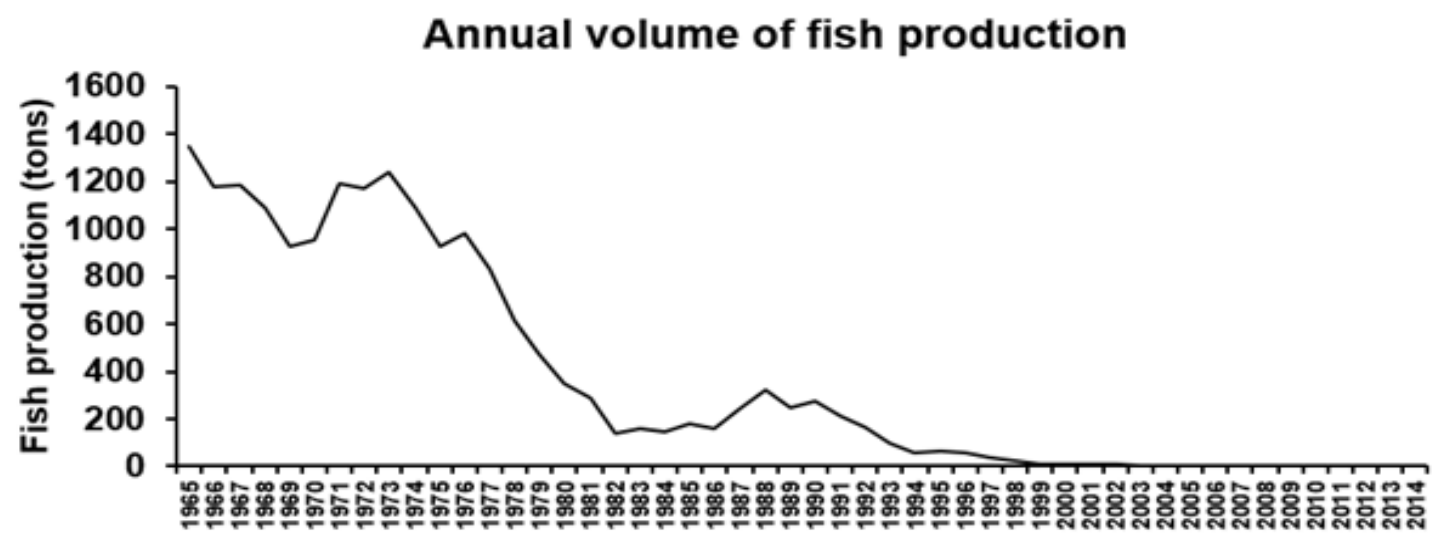

Figure 5: Annual fish production on Issyk-Kul lake.

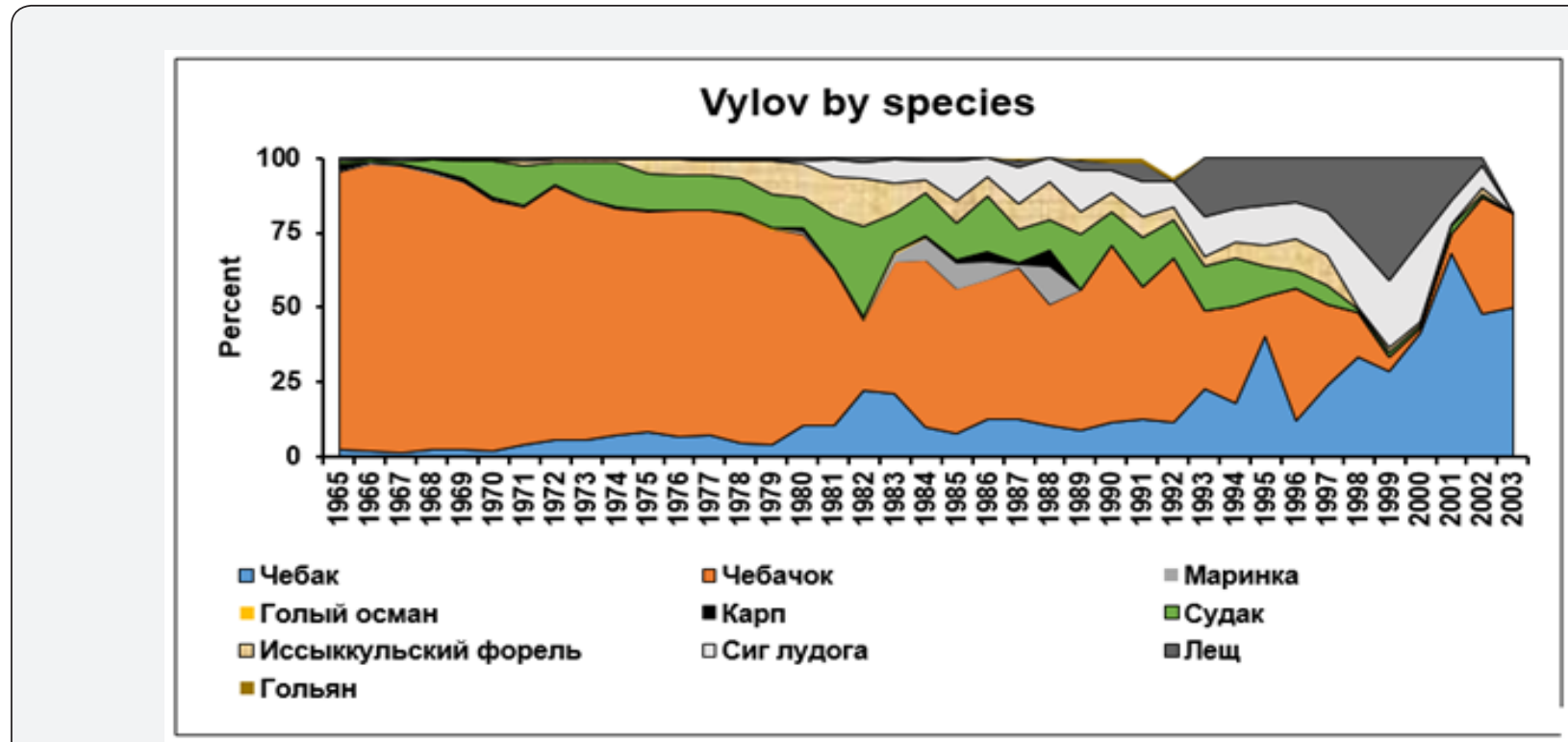

Figure 6: Species composition of catches on lake Issyk-Kul.

\section{Conclusion}

Systematic assessment of biodiversity indicators against the background of basic data indicates a possible recovery of endangered fish species on lake Issyk-Kul. It is necessary to conduct planned monitoring studies, as well as take effective measures to restore peaceful fish species and reduce the pressure of predatory fish species. Without controlling the pressure of predatory fish species, it is difficult to restore the population of declining endemic species in the lake. According to a well-established ecological principle, in an ecosystem where predatory fish species such as walleye, bream and their preychebak and chebachok coexist, the carrying capacity of predatory fish is determined by the abundance of prey, while the carrying capacity of victims is determined by the abundance of predators (Lotka 1925; Volterra 1926). This ecological principle has not been disputed for more than 90 years, and lake Issyk-Kul is no exception to this principle.

However, it is possible to control the pressure of predatory fish by controlling their populations, which are well established on lake Issyk-Kul. This can be done by targeted trapping of predatory fish, using selective trapping with certain fishing gear, such as permit for trapping predatory fish and controlling their populations, and it would also be more meaningful to protect the spawning areas of endemic fish species such as chebaka and chebachka during the peak of the spawning period. This can be implemented by introducing closed areas and closed seasons for any type of fishing. Data on biodiversity indicators in the framework of this work on the studied fishing areas of lake Issyk- 
Kul can be used as basic indicators for conducting monitoring studies to restore biodiversity in lake Issyk-Kul.

\section{Acknowledgment}

The authors express gratitude to the Food and Agriculture Organization of the United Nations in the Kyrgyz Republic, the Government of Finland and Institute of Biology NAS KR for financial support in conducting research.

\section{References}

1. Frunze (1956) Ichthyological collection. Academy of Sciences of the Kyrgyz SSR / Institute of Zoology and Parasitology.
2. Pivnev IA (1990) Fish of Kyrgyzstan 3-4.

3. Asanova AK, Totubayeva NE (2017) Analysis of the state of Issyk-Kul lake by hydrochemical indicators. NNTIC 3: 108-111.

4. Bishkek (2006) Third national report on biodiversity conservation of the Kyrgyz Republic.

5. Shannon CE, Weaver W (1949) The mathematical theory of communication. In: The University of Illinois Press, Urbana, Chicago, USA, Pp. 117.

6. Quinn G, Keough M (2002) Experimental Design and Data Analysis for Biologists. In: Cambridge University Press, Cambridge, England, Pp. 511.

\section{Your next submission with Juniper Publishers} will reach you the below assets

- Quality Editorial service

- Swift Peer Review

- Reprints availability

- E-prints Service

- Manuscript Podcast for convenient understanding

- Global attainment for your research

- Manuscript accessibility in different formats ( Pdf, E-pub, Full Text, Audio)

- Unceasing customer service

Track the below URL for one-step submission https://juniperpublishers.com/online-submission.php 